\title{
Evaluation of the Metabolic Profile During a Two Week Period in a Balneary Resort
}

\author{
Gavril Lucian Gheorghievici', Adriana Sarah Nica', Gabriela Radulian
}

\begin{abstract}
Introduction: The metabolic syndrome has become a public burden that raises numerous global healthcare issues, the search for new management strategies for these patients representing an ongoing concern. The study proposes the evaluation regarding the impact that therapeutic mineral waters and associated with dietary changes and adapted balneary programs may have over different metabolic conditions. Methods: We enrolled 237 patients with metabolic syndrome defined using 2017 IDF criteria that were monitored for a 12 day stay in the balneary resort. Biological levels were determined at admission and discharge. Additional anthropometric measures and nutrition aspects were determined. Crenotherapy was composed of different sources of mineral therapeutic waters with a composition that had a presence of hydrogen sulfide (sulphurous mineral waters), bicarbonate, calcium, magnesium mineral waters. Results: Body mass index and waist circumference and blood pressure determined at admission presented reduced values at the end of the balneary cure $(p<0.05)$. Nutritional aspects in the studied group revealed a tendency towards an unhealthy eating behavior, $65.82 \%$ of the patients being on a high meat consumption, and an insufficient amount of fruit and vegetables. Diminished values of fasting plasma glucose and HDIcholesterol were observed at discharge, while uric acid and tryglicerides did not present significant differences at the end of the cure compare to admission. Conclusions: Balneotherapy can provide a reduction of the parameters that define the metabolic syndrome. Due to its particular physical and chemical composition, mineral therapeutic waters used both internally and externally can represent an important tool in modulating the biological parameters responsible for the metabolic conditions.
\end{abstract}

Keywords: mineral therapeutic waters, metabolic syndrome, diabetes mellitus

\section{Rezumat}

Introducere: Sindromul metabolic reprezintă o problemă de sănătate publică ce necesită furnizarea continuă a unor noi soluții terapeutice. Studiul își propune evaluarea impactului pe care apele minerale terapeutice asociate cu modificări dietetice și programe balneare adaptate îl pot avea asupra diferitelor patologii metabolice. Material și metode: Au fost înrolați 237 de pacienți diagnosticați cu sindrom metabolic folosind criteriile IDF 2017 ce au fost monitorizați pe durata unei cure balneare de 12 zile. Parametrii biologici au fost determinați la începutul și la finalul curei. S-au realizat de asemenea măsurători antropometrice și ancheta nutrițională. Crenoterapia a fost compusă din diferite surse de ape minerale terapeutice sulfuroase, bicarbonate, calcice, magneziene. Rezultate și discuții: Indicele de masă corporală, circumferința abdominală și tensiunea arterială determinată la inițierea curei au prezentat valori reduse la finalul tratamentului balnear $(p<0,05)$. Aspectele nutriționale din lotul studiat au evidențiat o tendință către comportament alimentar nesănătos, 65,82\% dintre pacienți prezentând un consum ridicat de carne și o cantitate insuficientă de fructe și legume. S-au observat valori scăzute ale glicemiei și HDL-colesterolului la finalul tratamentului, în timp ce valorile acidului uric și ale trigliceridelor nu au prezintat diferențe semnificative. Concluzii: Apele minerale terapeutice pot oferi o reducere a parametrilor responsabili pentru definirea sindromul metabolic. Datorită compoziției fizice și chimice specifice, apele minerale utilizate atât în cura internă cât și externă pot reprezenta un instrument important în tratamentul diferitelor afecțiuni metabolice.

Cuvinte cheie: ape terapeutice minerale, sindrom metabolic, diabet zaharat

${ }^{1}$ "Carol Davila" University of Medicine and Pharmacy, Bucharest, Romania
Corresponding author.

Gavril Lucian Gheorghievici, "Carol Davila” University of Medicine and Pharmacy, Bucharest, Romania.

E-mail: gavril.gheorghievici@gmail.com 


\section{INTRODUCTION}

Metabolic syndrome (MetS) is defined as a cluster of elements represented by increased levels of fasting plasma glucose, raised tryglicerides, high blood pressure and modified values of HDL cholesterol associated with the presence of abnormal abdominal waist ${ }^{1,2}$. Due to this elements it represents a predicting factor regarding the development of type II diabetes and cardiovascular disease. Although insulin resistance ${ }^{3}$ and central obesity ${ }^{4}$ represent the main causative factors, there are still many unknown variables of its components that require further research.

The International Diabetes Federation (IDF) according to 2017 Diabetes Atlas expresses the fact the prevalence of MetS is continuously increasing, presently around $20-25 \%$ percent of the population worldwide is suffering from this condition, this adding to the existing population suffering from diabetes, and multiplying the risk of developing cardiovascular complications, most frequently being a heart attack ${ }^{5}$. The prevalence increases with age, especially during the six decade of life $\mathrm{e}^{6,7}$ the estimated risk of further developing diabetes being 5 to 7 times higher in these patients compared to patients absent of the pathology. In a meta-analysis ${ }^{8}$ on longitudinal studies regarding the cardiovascular impact, a higher risk of developing cardiovascular events was observed in case of a preexistent cardiovascular pathology, and also an increased risk when associated with other metabolic conditions such as obesity9.

Treatment options include lifestyle changes, which requires the adoption of a healthy diet, increased physical activity, smoking cessation plan and maintenance of a healthy body weight, physical exercise and pharmacological treatment of its different components if attempts to lifestyle changes are not adequate.

Balneotherapy has represented a useful tool of treatment in different chapters of pathology. Because of the diversity of its therapeutic factors it can cover a large area of treatment ${ }^{10}$. The use of mineral therapeutic waters have been proven beneficial due to both its physical and chemical particularities when administered internally, also through skin absorption when used externally ${ }^{11}$. In a study that observed the effectiveness of a three week cure in balneary resorts on weight loss, and it is suggested that balneotherapy associated with nutrition programs and phychological support can achieve a weight reduction in these patients ${ }^{12}$.

\section{MATERIAL AND METHOD}

We realized a pilot observational descriptive study, that developed in the balneary resort in which we monito- red the evolution of patients diagnosed with metabolic syndrome over a two week balneary program.

Including criteria regarded patients with age $>18$ years old previously diagnosed with metabolic syndrome using the IDF criteria according to the 2017 Diabetes Atlas. Exclusion criteria regarded patients with neoplasma, congestive heart failure, chronic kidney disease, diabetic complications. Anthropometric characteristics included body mass index (BMI) which was calculated dividing the body weight to the square height $\left(\mathrm{kg} / \mathrm{m}^{2}\right)$ and waist circumference which was determined using a division centimeter. BMI ranges are $25 \mathrm{~kg} / \mathrm{m}^{2}$ - normal, $25-30 \mathrm{~kg} / \mathrm{m}^{2}$ - overweight, and $>30 \mathrm{~kg} / \mathrm{m}^{2}$ - obese. Blood pressure (BP) was recorded manually at the beginning of the cure and at the end of the balneary treatment using a pressure manometer, on the right arm of the patients the targeted values being systolic $\mathrm{BP} \geq 130$ or diastolic $\mathrm{BP} \geq 85 \mathrm{~mm} \mathrm{Hg}$. Blood samples implied the determination of fasting plasma glucose, tryglicerides, HDL-cholesterol, uric acid, which were taken at admission and discharge.

Nutritional aspects were assessed using a validated questionnaire that included 10 questions regarding meat consumption, milk and dairy products, sweets, hydration status, smoking status, salt consumption, number of meals per day, level of physical activity, consumption of fruits and vegetables, coffee drinking. The balneary treatment that lasted for 12 days was composed of particularized kinetotherapy and hydrokinetoterapy programs associated with different forms of electrotherapy, massage and thermotherapy. Crenotherapy was composed of different sources of mineral therapeutic waters with a composition that had a presence of hydrogen sulfide (sulphurous mineral waters), bicarbonate, calcium, magnesium or mineral waters.

\section{Statistical Analysis}

Results were expressed under the form of mean and standard deviation (SD). The distribution of the variables was assessed using the Shapiro Wilk test. Wilcoxon Rank test was used to determine mean differences between non parametrical data, while Spearman correlation test was applied to determine associations between variables. A $p$ value less than 0.05 was considered significant. The statistical analysis was made using SPSS version 20.0. All participants signed an informal consent in which they understood and agreed upon the investigation that were to be made. The study was approved by the local ethical comission and received permission of the administration of the balneary resort. 


\section{RESULTS AND DISCUSSIONS}

We enrolled 237 patients diagnosed with metabolic syndrome according to IDF criteria, $47.25 \%$ male $/ 52.75$ female, mean age $67.37 \pm 8.69$. Other metabolic pathologies were also evaluated. Diabetes mellitus was present in 62 of the patients $(62.90 \%$ male/37.10 female) while 95 patients $(28.4 \%$ male/ 71.60 female) presented obesity and hypeuricemia was present in 23 patients (73.91\% male/26.09 female). Descriptive statistic regarding the socio-demographic characteristic of the evaluated group can be observed in Table 1 and Figure 1.

Table 1. Demographic characteristics of the studied group

\begin{tabular}{|l|c|}
\hline Variables & $\mathbf{N}(\%)$ \\
\hline Age (mean \pm SD) & $67.37 \pm 8.69$ \\
\hline Male & $47.25 \%$ \\
\hline Female & $52.75 \%$ \\
\hline Urban & $37.55 \%$ \\
\hline Rural & 62.45 \\
\hline Employed & $39.66 \%$ \\
\hline Retiree & $60.34 \%$ \\
\hline Primary school & $3.79 \%$ \\
\hline Gymnasium & $10.97 \%$ \\
\hline High school & $55.69 \%$ \\
\hline Post High School & $5.90 \%$ \\
\hline Faculty & $23.62 \%$ \\
\hline Smoker & $34.59 \%$ \\
\hline $\mathrm{n}=237$ & \\
\hline
\end{tabular}

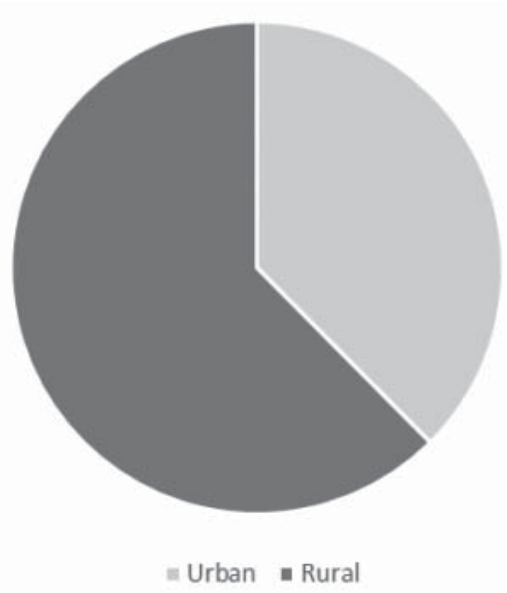

Figure 1. Urban/Rural status of the studied group.

Body mass index and waist circumference determined at admission presented reduced values at the end of the balneary cure $(\mathrm{p}<0.05)$. Blood pressure determined at admission (mean SBP $147.37 \pm 14.68$; mean DBP $89.32 \pm 12.28)$ presented a reduction at the end of the balneary cure without intervention in the pharmacological treatment (mean SPB 135.21 \pm 7.19 mean DBP $73.49 \pm 8.93 ; \mathrm{p}<0.05)$ Table 2.

Table 2. Determinations of the studied group

\begin{tabular}{|l|c|c|c|}
\hline $\begin{array}{l}\text { Variables } \\
\text { (mean/ 95\% C.I.) }\end{array}$ & Admission & Discharge & $\boldsymbol{p}$ \\
\hline $\mathrm{SBP}$ & $147.37 \pm 14.68$ & $135.21 \pm 7.19$ & $<0.05$ \\
\hline $\mathrm{DBP}$ & $89.32 \pm 12.28$ & $73.49 \pm 8.93$ & $<0.05$ \\
\hline $\mathrm{BMl}$ & $28.39 \pm 2.37$ & $28.26 \pm 2.49$ & $<0.05$ \\
\hline $\begin{array}{l}\text { Waist circumfe- } \\
\text { rence }\end{array}$ & $93.56 \pm 10.56$ & $92.24 \pm 10.21$ & $<0.05$ \\
\hline $\mathrm{n}=237$ & & \\
\hline
\end{tabular}

Nutritional aspects in the studied group revealed a tendency towards an unhealthy eating behavior, $65.82 \%$ of the patients being on a high meat consumption, $70.46 \%$ having daily salt diet and $40.92 \%$ consuming an insufficient amount of fruit and vegetables. Physical exercise was not reported regularly by the patients but was expressed through physical activity more than 30 minutes through daily activities in $78.48 \%$ of the patients. $76.37 \%$ of the patients consumed more de 1.51 of liquids per day, $64.97 \%$ had high salt intake, $40.51 \%$ consumed insufficient milk and dairy products, $36.2 \%$ consumed a large amount of sweets and $73.83 \%$ had more than 2 meals/day.

From the studied group, the biological profile was evaluated in 37 patients ( $45.94 \%$ male $/ 54.06 \%$ female), blood samples being determined at admission and at discharge. Mean FPG presented lower values at the end of the cure $(102.16 \pm 7.77)$ compared to admission (103.93 \pm 8.80$) \mathrm{p}<0.05$ (Figure 2) while a reduction regarding triglycerides value was detected, but not statistically significant $(167.95 \pm 33.12$ vs $167.11 \pm$ 31.63; $p=0.17)$. HDL cholesterol obtained better values at discharge compared to admission $(49.17 \pm 4.76$ vs $47.93 \pm 6.11 ; \mathrm{p}<0.05$ ) (Figure 3 ) while uric acid presented a small reduction at the end of the cure but without statistical significance $(6.07 \pm 1.05$. vs $6.08 \pm 1.09$; $\mathrm{p}=0.15)$. Results can be observed in Table 3 .

Table 3. Biological values in the studied group

\begin{tabular}{|l|c|c|c|}
\hline Variables $($ mean $\pm S D)$ & Admission & Discharge & $p$ \\
\hline FPG $(\mathrm{mg} / \mathrm{dl})$ & $103.93 \pm 8.80$ & $102.16 \pm 7.77$ & $<0.05$ \\
\hline Triglycerides $(\mathrm{mg} / \mathrm{dl})$ & $167.95 \pm 33.12$ & $167.11 \pm 31.63$ & 0.17 \\
\hline HDL-cholesterol $(\mathrm{mg} / \mathrm{dl})$ & $49.17 \pm 4.76$ & $47.93 \pm 6.11$ & $<0.05$ \\
\hline Uric acid $(\mathrm{mg} / \mathrm{dl})$ & $6.07 \pm 1.05$ & $6.08 \pm 1.09$ & 0.15 \\
\hline $\mathrm{n}=37$ & \multicolumn{4}{|l}{} \\
\hline
\end{tabular}




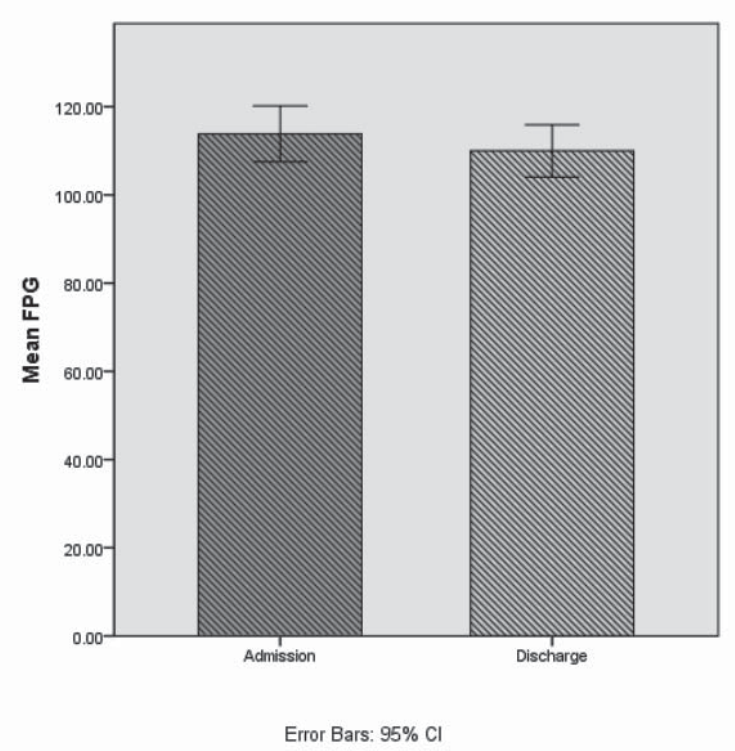

Figure 2. Comparison between FPG levels at admission and discharge.

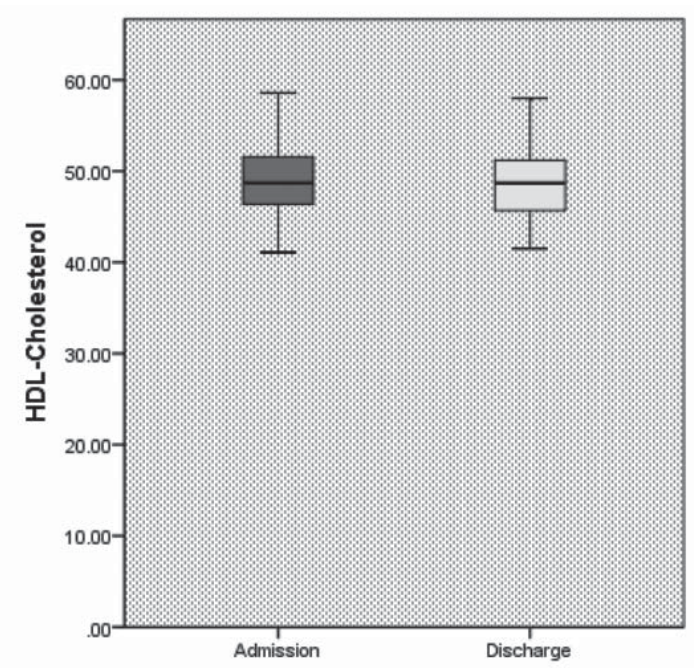

Figure 3. Comparison between HDL-cholesterol levels at admission and discharge.

Hypertension was present in $80.59 \%$ of the patients from the evaluated group. In a study that developed in the balneary resort which evaluated the development of selected cardiovascular parameters in patients with type II diabetes, the authors used different sources of mineral waters that include free $\mathrm{CO}_{2}$ dissolved in water in a dissociated form both internally and also associated with other balneary forms of treatment and dietary interventions, the authors observed a reducing of the sympathoadrenal system activity in patients with poorly controlled diabetes type II, associated with an improvement of the electrical stability of the myocardium and heart rate variability without an overload of the cardiovascular treatment. Immersion in mineral waters containing high concentration of $\mathrm{CO}_{2}$ might activate parasympathetic nerve activity in humans and could induce peripheral vasodilatation ${ }^{13}$.

Balneotherapy has been associated with an improvement of sleep quality. Sleep deprivation is considered to be responsible for mood changes, mostly due to the fact that it involves modifications in autonomic modulations, sleep deprivation along with the modification of circadian rhythm being held responsible for occupational stress ${ }^{14,15}$. Studies suggest that prudent dietary programs consisting mostly of vegetables and fruit could be beneficial for sleep architecture ${ }^{16}$. Multiple hypothesis have emerged regarding the mechanism of action in case of balneary cure on anxiety manifestations, including reduction of salivary cortisol levels after spa bathing ${ }^{17}$, modifications regarding the platelet serotonin transporter, and also of the symphatetic tone in case of warm footbath the authors concluding that balneotherapy is more effective in stress reduction compared to the control group ${ }^{18}$.

Crenotherapy may provide a modulation of the parameters that define obesity and diabetes, due to the fact that these conditions can occur as a result of the interference of gastric pathology, associated with hepato-biliary, and pancreatic manifestations. Our research suggests an effect over the lipid profile of the patient. In a study that evaluated the effect of sulphate-bicarbonate-calcium water on risk factors for atherosclerosis, weight control, and gallstone disease over a 12 day cycle in patients with functional dyspepsia and constipation, in which the authors evaluated total/low density lipoprotein and high density lipoprotein, bile acid, and the fasting gallbladder volume using the ellipsoid formula on the average of 2 sonographical gallbladder measurements, the authors observed an improvement intestinal transit and allows maintenance of a stable body weight despite a high food intake. Fasting gallbladder volume was significantly smaller at the end of the study than at baseline in the mineral water group $(15.7 \pm 1.1 \mathrm{~mL}$ vs $20.1 \pm 1.7 \mathrm{~mL}$ ) compared to tap water group (19.0 $\pm 1.4 \mathrm{~mL}$ vs $19.4 \pm 1.5 \mathrm{~mL}$ ). There were no significant difference regarding biological profile at the end of the cure compared to baseline - total cholesterol ( $\mathrm{mg} / \mathrm{dL}$ )mineral water $178.7 \pm 5.8$ vs $182.4 \pm 6.3$, control 181.5 \pm 7.6 vs $177.4 \pm 6.5$-HDL cholesterol $(\mathrm{mg} / \mathrm{dL})$-mineral water $(62.3 \pm 4.7$ vs $63.7 \pm 4.7)$, control water $(56.7 \pm$ 5.0 vs $59.4 \pm 6.1)-\mathrm{LDL}$ cholesterol $(\mathrm{mg} / \mathrm{dL})-$ mineral water $(100.4 \pm 8.0$ vs $101.9 \pm 8.7)$, control water $(103.6$ \pm 8.5 vs $93.9 \pm 7.7)$ - triglycerides $(\mathrm{mg} / \mathrm{dL})$ mineral water $(79.9 \pm 7.5$ vs $84.0 \pm 10.2)$, control water $(106.1 \pm$ 11.4 vs $120.7 \pm 17.9)^{19}$. 
In another study on 19 healthy patients regarding the effect of bicarbonate-rich mineral water over glycemic control the authors evaluated fasting plasma glucose, serum glycoalbumin, insulin, total cholesterol, HDL cholesterol, LDL cholesterol, and triglycerides, sodium, chlorine, calcium, and magnesium, observing a reduction of serum albumin levels and a significant increase in blood calcium levels possible due to the waters high calcium concentration $(177 \mathrm{mg} / \mathrm{kg})^{20}$.

The use of balneary cure in patients with obesity can be obtained through adapted programs that imply both the use of mineral therapeutic waters in intern cure for its physical and chemical characteristics, and also externally in hydrokinetotherapy programs. Another influence can be manifested by the bioclimate, which depending on the selected resort has either sedative, or tonic-stimulating effects, which can be added to the global effect provided by the balneary resources ${ }^{21,22}$.

The encouragement of physical exercise over the two week period can be considered a premise for further implementation of weight loss programs and adherence contribute to weight loss in patients with obesity and when associated with dietary modifications and nutritional counselling can improve weight status for these patients. In a study ${ }^{12}$ that evaluated the effect of a balneary program in weight reduction in patients with obesity, the authors observed a comparable efficiency in the group that received crenotherapy with mineral therapeutic waters, hydrokinetotherapy and dietary compared to the control group that received only pharmacological treatment with agonists of $2 \mathrm{C}$ receptors of serotonine- Lorcacerin- and lifestyle modifications.

\section{Limitations of the study}

One of the major limitations of the study is the small sample of patients, the absence of a control group and the lack of randomization. Although nutritional aspects and lifestyle aspects were assessed through a questionnaire, due to the fact that they were made in a cross-sectional matter an cannot comply to a larger prospective analyses they are at risk of bias, and also depend on the reliability of the patient. Another aspects regards the fact that not all lifestyle parameters were taken under considerations, and also that the balneary program included multiple treatment options and not only the administration of MTW, therefor an individual effect cannot be separated.

\section{CONCLUSIONS}

Diminished values of fasting plasma glucose and HDL-cholesterol were observed at discharge, while uric acid and tryglicerides did not present significant differences at the end of the cure compare to admission. Anthropometric determinations and blood pressure were modified at discharge compared to beginning of treatment. Nutritional evaluation of the studied group revealed a tendency towards unhealthy patterns.

Mineral therapeutic waters can achieve a correction of the biochemical parameters that define the metabolic syndrome. Due to its particular physical and chemical composition, mineral therapeutic waters can be used both internally and externally and can represent an important tool in modulating the biological parameters responsible for the metabolic conditions.

Conflict of interests: The authors express the fact that there are now conflicts of interest regarding the publication of this article.

Acknowledgement: This paper is supported by the Sectorial Operational Programme Human Resources Development (SOP HRD), financed from the European Social Fund and by the Romanian Government under the contract number POSDRU/187/1.5/S/156069/.

\begin{tabular}{|c|c|}
\hline \multicolumn{2}{|c|}{ Abbreviations: } \\
\hline iDF & International Diabetes Federation \\
\hline MetS & Metabolic Syndrome \\
\hline MTW & mineral therapeutic water \\
\hline BMI & Body Mass Index \\
\hline WC & Waist circumference \\
\hline BP & Blood pressure \\
\hline
\end{tabular}

dyslipidemia, and atherosclerotic cardiovascular disease. Diabetes Care 14:173-194

4. Kahn BB, Flier JS 2000 Obesity and insulin resistance. J Clin Invest 106:473-481

5. Q\&A: Key points for IDF Diabetes Atlas 2017 Diabetes Research and Clinical Practice, Volume 135, 235-236

6. Park YW, Zhu S, Palaniappan L, Heshka S, Carnethon MR, Heymsfield SB 2003 The metabolic syndrome: prevalence and associated risk factor findings in the US population from the

\section{References}

1. Alberti KG, Zimmet $P$, Shaw J; IDF Epidemiology Task Force Consensus Group. The metabolic syndrome a new worldwide definition. Lancet 2005;366:1059-62.

2. Alberti KG, Zimmet $P$, Shaw J. Metabolic syndrome-a new world-wide definition. A Consensus Statement from the International Diabetes Federation. Diabet Med 2006 May;23(5):46980

3. DeFronzo RA, Ferrannini E 1991 Insulin resistance.A multifaceted syndrome responsible for NIDDM, obesity, hypertension, 
Third National Health and Nutrition Examination Survey, 19881994. Arch Intern Med 163:427-436

7. Flegal KM, Carroll MD, Kuczmarski RJ, Johnson CL 1998 Overweight and obesity in the United States: prevalence and trends, 1960-1994. Int J Obes Relat Metab Disord 22:39-47 61. Mokdad AH, Bowman BA, Ford ES, Vinicor F, Marks JS, KoplanJP 2001 The continuing epidemics of obesity and diabetes in the United States. JAMA 286:1195-1200

8. Apoor S. Gami, Brandi J. Witt, Daniel E. Howard, , Patricia J. Erwin, Lisa A. Gami, RN, Virend K. Somers, Victor M. Montori, Metabolic Syndrome and Risk of Incident Cardiovascular Events and Death A Systematic Review and Meta-Analysis of Longitudinal Studies Journal of the American College of Cardiology Vol. 49, No. 4, 2007

9. Meigs JB et al. Body mass index, metabolic syndrome, and risk of type 2 diabetes or cardiovascular disease. J Clin Endocrinol Metab 2006; 91 (8):2906-2912.

10. Bender T, Bálint G, Prohászka Z, Géher P, Tefner IK Evidence-based hydro- and balneotherapy in Hungary--a systematic review and meta-analysis. Int J Biometeorol. 2014 Apr;58(3):311-23

11. Gaál J, Varga J, Szekanecz Z, Kurkó J, Ficzere A, Bodolay E, Bender T. Balneotherapy in elderly patients: effect on pain from degenerative knee and spine conditions and on quality of life. Isr Med Assoc J. 2008 May;10(5):365-9.

12. Hanh T, Serog P, Fauconnier J, Batailler P, Mercier F, Roques CF, Blin P. One-year effectiveness of a 3-week balneotherapy program for the treatment of overweight or obesity. Evid Based Complement Alternat Med. 2012;2012:150839.

13. Sato M, Kanikowska D, Iwase $S$ et al. Effects of immersion in water containing high concentrations of $\mathrm{CO} 2$ (CO2-water) at thermoneutral on thermoregulation and heart rate variability in humans. Int J Biometeorol. 2009 Jan;53(1):25-30. doi: 10.1007/ s00484-008-0188-x. Epub 2008 Oct 24
14. Zare R, Choobineh A, Keshavarzi S. Association of Amplitude and Stability of Circadian Rhythm, Sleep Quality, and Occupational Stress with Sickness Absence among a Gas Company Employees-A Cross Sectional Study from Iran. Saf Health Work. 2017 Sep;8(3):276-281

15. Cao Y, Taylor AW, Wittert G, Adams R, Shi Z, Dietary patterns and sleep parameters in a cohort of community dwelling Australian men. Asia Pac J Clin Nutr. 2017;26(6):1158-1169

16. Toda M, Morimoto K, Nagasawa S, Kitamura K. Change in salivary physiological stress markers by spa bathing. Biomed Res. 2006 Feb;27(1):11-4

17. Rapolienè L, Razbadauskas A.,Sąlyga J., Martinkènas A. Stress and Fatigue Management Using Balneotherapy in a Short-Time Randomized Controlled Trial Evidence-Based Complementary and Alternative Medicine, vol. 2016, Article ID 9631684, 10 pages, 2016.

18. Latorre-Román PÁ, Rentero-Blanco M, Laredo-Aguilera JA et al. Effect of a 12-day balneotherapy programme on pain, mood sleep, and depression in healthy elderly people. Psychogeriatrics. 2015 Mar;15(1):14-9

19. Corradini SG, Ferri F, Mordenti $M$, et al. Beneficial effect of sulphate-bicarbonate-calcium water on gallstone risk and weight control. World Journal of Gastroenterology: WJG. 2012; 18(9):930-937

20. Murakami, Shinnosuke Goto Yasuaki Ito, Kyo et al. The Consumption of Bicarbonate-Rich Mineral Water Improves Glycemic Control. Evidence-Based Complementary and Alternative Medicine. 2015. 1-10. 10.1155/2015/824395

21. Balneoclimateric cure - Indication and counterindications. Ed Medicala. Bucharest 1986

22. Nica A.S. Crenotherapy in renourinary pathologies. Ed Prospect Antropos 1997 